\title{
Village Fund Policy Implementation Model in Efforts to Reduce Poverty Rate
}

\author{
ISMET SULILA \\ Program Study IImu Administrasi Publik, Universitas Negeri Gorontalo, Indonesia \\ Correspondence author: ismet.sulila@gmail.com
}

\begin{abstract}
Village fund is used to support the activities of village autonomy to be more optimal in providing services to the community, development, and rural community empowerment. This study aims to examine the implementation of village fund in Bone Bolango Regency, the factors determining effectiveness of village fund policy, and the development of a community empowerment model through the use of village funds. This study is conducted for three months and employs a qualitative method to answer those three problems above. The results show that 1 ) the implementation of village fund comprises six stages; 2 ) there are three supporting and obstructing factors in implementing village fund policy; 3 ) the implementation model development of village fund policy is based on an empirical study on determining factors in Bone Bolango Regency.
\end{abstract}

Keywords: empowerment, village fund, poverty.

\section{Introduction}

The Act Number 9 of 2015 on Local Government and Act Number 33 of 2004 on Financial Balance between Central and Local Governments are expected to bring up fundamental changes in the process of policymaking and the development management in the region. Such changes demand a quick and dynamic role from the local executive and legislative to guarantee the realization of regional financial management that can improve the efficiency and effectiveness of public services, economic growth, and community welfare by concerning transparency and accountability.

The principle of autonomy requires the related region to regulate and handle its own business, either government affairs or regional development. Regional autonomy certainly needs a fund that should be provided by the region by discovering its economic potential, so that the region's capability becomes an important prerequisite in performing the regional autonomy itself. The rural community still faces the issues of poverty, backwardness, and difficulty in accessing public services. This condition leads to the need for equitable development and public financial support for the villagers. The state budget allocation for villages is expected to attract community involvement in the development. The Nawacita (nine missions) concept that currently becomes a priority program of the Indonesian government is started by strengthening the development of regions and villages in Indonesia. Therefore, the Act Number 6 of 2014 on Villages is intended to create independent villages and to empower the community as by the villages' potential. Moreover, the stipulations regulating the source of village fund in the development are Government Regulation Number 60 of 2014 on Village Fund and Government Regulation Number 43 of 2014 on Implementation Regulation of Act Number 60 of 2014 on Villages.

Rural development is one of the villages' authorities. The implementation of this development certainly requires financial support or village financing sources. One of the sources of village revenue is the central and local financial balance fund received by the regency/city in which the fund for each village is distributed proportionally, and it is called village fund. In addition, the village fund will be used to support the activities of village

Received: 20-07-02, Revised: 2020-10-13, Accepted: 2020-12-30

Print ISSN: 0215-8175; Online ISSN: 2303-2499. DOI:https://doi.org/10.29313/mimbar.v36i2.6358

Accredited Sinta 2 based on the decree No.10/E/KPT/2019 until 2024. Indexed by DOAJ, Sinta, Garuda, Crossreff, Dimensions 
autonomy to be more optimal in providing services to the community, development, and rural community empowerment. According to Rozaki et al. (2005:120), the village fund policy is intended to overhaul the orthodoxy of regency governments in giving authorities, services, and financial support to the subdistrict governments. The policy pattern of the regency governments which was originally dominant and centralist, through this allocation method of village fund, has turned into a participatory and responsive pattern and carried out through the principle of decentralization. Village Funds as source of village income have a strategic role in supporting village development (Chasanah: 2017). Prasetyo (2014:302) argues that in a framework of village autonomy, all forms of village government affairs become the village authority, including the management of the village finance. Financial decentralization to villages is a positive thing in the context of accelerating development and realizing village autonomy (Wahyuddin: 2019). In the context of village fund, there are five important reasons causing a village needs sources of revenue, which are: 1) Village is the government's fulcrum in public services, 2) Village has a small Village Revenue and Expenditure Budget, and its sources highly depend on the small support as well, 3) Rural community's low welfare that makes it difficult for the village to gain a high Village Own-Source Revenue, 4) Low village operational fund to public services, 5) Several development programs of the village, yet they are managed by local government organization.

Based on the Government Regulation Number 43 of 2014 on Implementation Regulation of Act Number 60 of 2014 on Villages, the details of Village Expenditure set in Village Revenue and Expenditure Budget are $30 \%$ for the village government, routine costs such as operational costs, allowance, fixed income, and official travel expenses. However, $70 \%$ of its use is to fund the village administration and development, community development and empowerment. Sumaryadi (2005:150) states that three approaches in the process of community empowerment are as follows: 1 ) the welfare approach: assisting particular groups. 2) the development approach: focusing on the improvement of the community's independence, ability, and self-supporting. 3) the empowerment approach: seeing poverty as a political process and attempting to empower or train people to overcome their helplessness. The Village Fund is intended to finance village government programs in terms of implementing government activities and community empowerment (Aswar: 2017). Therefore, the use of Village Funds can meet the development and empowerment needs of rural communities (Winarni: 2016). By the policy of village fund, the most vital thing in implementing the village fund budget is the independence and ability to utilize the management of village fund in terms of effective and efficient community empowerment and poverty reduction.

Bone Bolango Regency in Gorontalo Province is established by Act Number 6 of 2003 on Establishment of Bone Bolango Regency and Pohuwato Regency in Gorontalo Province. This regency comprises 160 villages, five urban villages, and 18 sub-districts. According to the Central Bureau of Statistics of Gorontalo Province, the total population of Bone Bolango Regency was 157,186, consisting of 78,816 male population and 78.370 female population in 2017. Poverty in Bone Bolango Regency reached $17.97 \%$ with a total of 27,800 poor people in 2016 . One of the real solutions to reduce the poverty rate is by implementing the policy of village fund. Village fund is originally from the State Budget intended for villages that are transferred through Regional Revenue and Expenditure Budget of the regency. The fund is used to finance the government administration, area development and community development and empowerment. Therefore, the implementation of village development which is related to the management of village funds must remain focused and sustainable in accordance with the policies that have been outlined (Kamaludin: 2018). The success of development in the regions is a series of successes from the village to district levels. Therefore, the implementation of village government must be carried out properly because it is part of the regent's responsibility (Mustanir: 2016). The data from DPMD of Bone Bolango Regency show that the realization of the village fund for the past four years is presented in table 1.

\section{Table 1 \\ Realization of the Village Fund in Bone Bolango Regency}

\begin{tabular}{cccc}
\hline No & Year & Realization & $\begin{array}{c}\text { Increase/ } \\
\text { Decrease } \\
(\%)\end{array}$ \\
\hline 1 & 2017 & $122.032 .055 .400,-$ & -
\end{tabular}




\begin{tabular}{llll}
2 & 2018 & $125.170 .634 .255,-$ & 2.57 \\
3 & 2019 & $140.603 .867 .151,-$ & 12.33 \\
4 & 2020 & $127.110 .849 .254,-$ & 1.12 \\
\hline
\end{tabular}

Source: Village Government Office of Bone Bolango Regency, 2020

The Table 1 indicates that the village fund had increased by $2.57 \%$ from 2017 to 2018. Further, from 2018 to 2019, the fund also went up to a higher percentage of $12.33 \%$ as well as increased by $1.22 \%$ in 2020 . Village fund that continues to increase from year to year has been used to finance development activities in various fields, including village infrastructure development, rural community empowerment, productive economics, social community, and other development priorities.

Based on the data from the Central Bureau of Statistics of Bone Bolango Regency, the total poor population over the past four years is shown in Table 2.

Table 2

Total Poor Population in Bone Bolango Regency

\begin{tabular}{cccc}
\hline No & Year & $\begin{array}{c}\text { Population } \\
\text { (Persons) }\end{array}$ & $\begin{array}{c}\text { Increase/ } \\
\text { Decrease } \\
(\%)\end{array}$ \\
\hline 1 & 2016 & 27.80 & - \\
2 & 2017 & 27.91 & 0.40 \\
3 & 2018 & 27.61 & -1.07 \\
4 & 2019 & 25.91 & -6.16 \\
\hline
\end{tabular}

Source: Central Bureau of Statistics of Bone Bolango Regency, 2020

Table 2 reveals that the poverty rate in the site area has fluctuated. In 2017, poverty had increased by $0.40 \%$, yet it went down to $1.07 \%$ in 2018. Furthermore, it decreased again by 6.16 in 2019. Theoretically, the greater the number of village fund used for village infrastructure development, community development, and empowerment, the lesser the poverty. It is in line with Abidin (2015:62) that along with a large number of Village Fund, the poverty issue is still difficult to resolve. Based on the data comparison from table 1 and table 2, it is found that the implementation of village fund and its increase for the past four years is not directly proportional to the decreased number of the poor population in Bone Bone Bolango Regency. As a result, it is essential to conduct a study on "Village Fund Policy Implementation Model in Efforts to Reduce Poverty Rate in Bone Bolango Regency" focusing on policy implementation, determining factors, and model development.

\section{Research Methodology}

Consequently, this study employed a qualitative descriptive method in analyzing the data. This study was conducted for three months at DPMD (Community and Village Empowerment Office) of Bone Bolango Regency as well as the selected sub-districts and villages. Based on the focus of the study, the method used is research and development. This method is intended to conduct in-depth studies and design new models for the implementation of village fund policies in poverty alleviation.

The data used in this study are 1) Primary data on the stages of planning, allocating, implementing and evaluating village funds and various factors that determine the effectiveness of village funds; 2) Secondary data on the allocation of village funds each year, the realization of village fund distribution and the impact of village fund policies. The required data were obtained from key informant sources. In model development research, informants do not emphasize the number that represents the subject as a whole, but rather represent the characteristics of the research subject.

Lawrence (2000:196) notes that informants can easily communicate, understand the needed information, and give information to the researcher to obtain accurate data. Key informants are those who considered having information or in-depth knowledge regarding the problems of research in which they are precisely becoming the research informants. Lawrence (2000:199) also mentions four characteristics of a good informant, such as: (1) understanding the culture of the site area and witnessing important events, living and undergoing the local culture, and being involved in routine activities in that place; (2) being involved in the field at the research period; (3) having plenty of time with the researcher; (4) being a non-analytical party.

Therefore, the informants in this study were the Head of DPMD of Bone Bolango Regency as the policymaker related to local regulation, the Head of Community Empowerment Division and the head of sub-program along with the selected village apparatus and rural community in Bone Bone Bolango Regency as the policy implementer. The data collection involves the following 
techniques: Observation, In-depth Interview, and Documentation. The data analysis technique was adjusted to the types of data and the methods of data collection employed. The data obtained from a qualitative approach usually involved some analysis steps, which are: processing, organizing, classifying, and synthesizing the data along with looking for the pattern, finding out the significant things to be learned, and determining the researcher's report. The data were analyzed descriptively, intended to describe the implementation model of the village fund policy in reducing the poverty rate in the site area with three sub-focuses, which are: (1) policy implementation; (2) determining factors, and (3) model development.

As argued by Miles, Huberman and Saldana (2014:31-33), there are three stages of qualitative data analysis, including: (1) Data Condensation is a process of selecting, simplifying, abstracting, and transforming data that approach all parts of written field notes, interview transcripts, and empirical documents and materials. Data condensation included the data of policy implementation, determining factors, and the development of an implementation model of the village fund policy in reducing the poverty rate in Bone Bolango Regency; (2) Data Display is a process of organizing, a unification of information that allows inference and action. It helps to understand phenomena and to do something, including a more in-depth analysis or taking action based on understanding. The presented data comprised the implementation of the village fund policy, the supporting and obstructing factors, and the development of an implementation model of the village fund policy in reducing the poverty rate in Bone Bolango Regency; (3) Conclusion Drawing. From the initial process of collecting data, qualitative analysts start to seek the meaning of objects, note the regularity of the explanation, possible configurations, flow of cause and effect, and proposition.

A final conclusion might not come up until the data collection is ended, depending on the number of field notes, coding, storing, the used method of re-search, and the researcher's skill. The presented data consisted of the implementation of the village fund policy, the supporting and obstructing factors, and the development of an implementation model of the village fund policy in reducing the poverty rate in Bone Bolango Regency.

\section{Results and Discussion \\ The Implementation of Village Fund Policy in Bone Bolango Regency}

According to Lester and Stewart (2000:104), implementation refers to the law of implementation by which actors, organizations, procedures, and techniques cooperate to undergo a policy to achieve the goals of the policy or programs. Similarly, Anderson (1984:3) states that policy implementation is an action that has particular goals, performed by one or more actors to solve a problem. Empirically, the management of village fund in Bone Bolango Regency comprises the following mechanisms: Firstly, Planning. The planning stage is the initial activity in managing village fund, aimed at drawing up a plan of activities and specifying the budget to be listed in List of Activity Plans (henceforth called as DRK). After DRK has been compiled, the village head as the person in charge forms an implementation team of village fund, consisting of the technical implementation of the village finance management and the treasurer. Secondly, Distribution. This stage is performed after the DRK and other administrative appendixes have been prepared and approved to be submitted to the sub-district head for review. Further, the sub-district head collectively delivers them to the DPMD of Bone Bolango Regency and forwarded to Regional Revenue and Asset Management Office. The disbursement of the village fund budget is carried out in three stages in a year; $40 \%$ in the first stage, $40 \%$ in the second stage, and $20 \%$ in the last stage. Thirdly, Implementation. This stage is the realization of all planning of the village fund management that has been approved. The village fund received are used for the administration costs which are provided to each station. The costs of community empowerment are also handed over to the village-level implementation team that will later be accountable to the village head. The implementers include the village head, youth organization, family welfare program team, and the community. Fourthly, Supervision. This stage is required to avoid program deviation. The village head and the implementation team of the village fund management do direct supervision. The indirect supervision, in contrast, is in the form of written Progress Report of the village fund. Unfortunately, the villagers seem not to concern with the program since they have not supervised the program yet. In fact, supervision from the community is essential 
to avoid errors, misappropriation, or any other undesirable things. Fifthly, Accountability. This stage is handled administratively in the form of a Progress Report with a financial format that has been stipulated in the applicable regulation. The progress report is a manifestation of the village administrative accountability to the higher-level government; meanwhile, the accountability of the village government to the community still needs to be realized factually and continually. Sixthly, Transparency. Such transparency is by having a meeting with the community's representatives and related institutions discussing the progress of the village fund. In this stage, the community has not had any enthusiasm with the government's attempts.

The stages of the village fund management in Bone Bolango Regency over the past four years are shown in figure 1 .

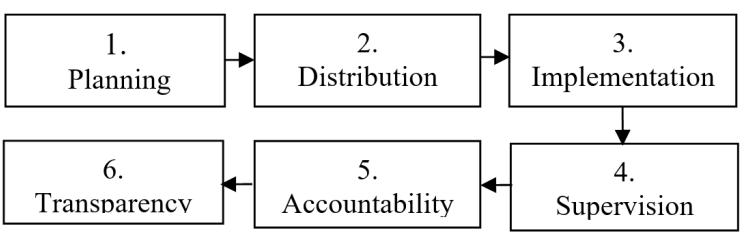

Figure 1. Stages of the Village Fund Management

From the context of rural community empowerment in Bone Bolango Regency, the village fund also focuses on three important components, such as 1 ) environmental empowerment is allocated for the development of physical facilities and infrastructure that can support the community's mobility; 2) economic empowerment is in the form of productive economic activities for Micro, Small, and Medium Enterprises groups and other productive businesses; 3 ) human empowerment is allocated to support youth activities through youth organization, utilized to buy sports and art items.

\section{Factors Determining the Implemen- tation of Village Fund in Reducing the Poverty Rate in Bone Bolango Regency}

\section{Supporting Factors}

Factors supporting the implementation of village fund policy are factually considered able to help and facilitate the implementers in achieving the village fund' goals and benefits. Those factors are empirically elaborated: (1) Policy supports. Policy is a concept that has become basic guidelines for the government to undertake a program. The policy is in the form of Regent Regulation and technical implementation instructions of the village fund management that become the supporting factors of village fund management. Empirical facts indicate that there is Bone Bolango Regent Regulation Number 6 of 2018 on Technical Instructions for Village Fund Distribution from the Regency Government to the Village Government. Such a policy has become the basis of reference in distributing fund to 160 villages. Theoretically, the importance of policy supports is claimed by Anderson (1984:3) that policy implementation is an action that has particular goals and performed by one or more actors to solve a problem. However, the implementation of Village Fund policies that have not been maximized and comprehensive can be due to incomplete Regent Regulations (Fahri: 2017).

(2) Village fund socialization. Socialization is a process of teaching the targets of policy. Facts empirically show that the socialization of village fund program is conducted in the form of a meeting and discussion. The community and other stakeholders attend the discussion of village development plans. Socialization is intended to assist the targets to understand more about the new policy that will be implemented. It needs a quite-long process to apply the new regulation, program, or activity. The socialization of the village fund management to the community and village government provides a positive impact on the management of the village fund itself. Theoretically, the significance of socialization as noted by Abdulsyani (2007:74) is that socialization is a learning process done by individuals to act or behave based on the standards acknowledged in society. Socialization is referred to an effort to integrate cultural values towards individuals to make them be parts of the community. Outreach to the community is further enhanced to help disseminate information and understanding about the development program that will be carried out. Thus the community will be easier to get involved in and contribute to the implementation of village government programs (Ridwan: 2019).

(3) Facilities and infrastructure. Facilities are a means to achieve goals or targets; meanwhile, infrastructure is the main support for the implementation of a process. Empirical data indicates that the availability of facilities and infrastructure in villages of Bone Bone Bolango Regency 
has become an essential aspect to exist, maintain, and utilize in supporting the implementation of the village fund policy. Important public facilities are a public meeting hall, transportation, computer and internet network, office services, and other facilities owned by the village government. Moenir (1992:119) theoretically brings up the value of facilities and infrastructure as a means or work equipment functioning as the primary support of work as well as any interests regarding work organizations. Office facilities as support have not been fulfilled, such as computer equipment and workspaces, will be one of the inhibiting factors in carrying out activities (Riadi: 2020).

The supporting factors of the implementation of village fund policy in Bone Bolango Regency are presented in figure 2.

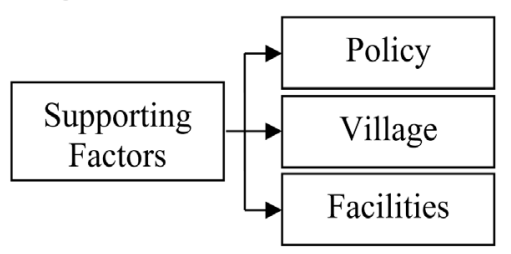

Figure 2. Supporting factors of Village Fund

\section{Obstructing Factors}

Factors that factually obstruct the implementation of village fund in the field and require concrete solutions. Empirical explanations of each factor are as follows: 1) Human resources. Village's human resources in Bone Bolango Regency have not been adequate in implementing the village fund policy. This condition is due to the educational level that has not met the requirements, the lack of technical guidance of the village fund management, and the lack of budgeting needs of human resources improvement. The lack of knowledge about regulations causes village financial management to run poorly (Anwar: 2020). In addition, there is also a need for training related to the implementing team in managing village funds and continuing to encourage the community to participate in program implementation (Hertati: 2018). Another empirical fact reveals that the increased village fund has been followed by the improvement of personnel's capacities in managing the village fund. This can cause the increased costs of human resources if asking for assistance from other parties in supporting various duties and implementation of programs in villages. In the end, it is impactful on the independence of managing the village fund. Theoretically, the importance of human resources management explained by Rokhman (2011:3) is that it manages and organizes human resources functions in terms of achieving organizational goals effectively and efficiently. 2) Community's active participation. It refers to the active involvement of the rural community that voluntarily contributes to the program from the planning to the evaluation process. Village development basically focuses more on active community participation and building village community self-help (Mulyadi: 2019). Village community participation in the process of village development activities is still low. This shows that the public's awareness of having a sense of belonging to existing development activities is still lacking (Herlina: 2018). The higher the community's participation as the program targets, the greater the goal achievements success level of the program. On the contrary, non-optimal participation of the community will lead to a low success level of the program. Data empirically show that the community's participation in the program planning and its implementation has not been realized completely due to people's busy work, domination of village apparatus, and people's ignorance in the program of village fund policy. Theoretically, Suryono (2001:124) mentions the advantages of community's participation such as being involved in the development as well as utilizing the outcomes of the development itself. It is supported by Slamet (1994:7) that participation is a person's or communities active role in the process of needs formulation, planning and implementation of the activity either by contributing ideas or giving physical supports. 3) Village Fund Supervision. Supervision is required to ensure that the village fund policy has been successfully implemented as in line with the set targets. Supervision can be carried out by the authorized government or directly by the community as the targets. Empirical facts reveal that supervision has been performed in stages by the government through organizational structures with a clear range of controls and division of works. Somehow, the lack of community's supervision is still encountered due to the ignorance of their rights and responsibilities in the supervision of village fund, limited knowledge of supervision, and opportunity for participating in the supervision. Theoretically, supervision noted by Makmur (2011:176) is a form of thinking and action patterns to provide an understanding and awareness to someone or some people who are given tasks 
to be accomplished using a variety of available resources. Thus, real errors and deviation that can inflict a loss to the institution or organization do not occur. Irregularities in village funds that often occur are partly due to weak supervision. There are several factors that hinder policy implementation, including ineffective supervision (Pratama: 2019). Program policies aimed at villages still encounter many obstacles so that they have not been able to optimally have an impact on improving community welfare. One of them is a weak program monitoring control mechanism, so that program implementation does not have a learning effect for program improvement (Utama : 2019). Diverted village funds will hinder village economic growth. To prevent undesirable things in the use of village funds, one way is transparency and the active role of citizens to participate in monitoring the use of village funds (Crisbiantoro: 2019).

Figure 3 is the obstructing factors of the implementation of village fund policy in Bone Bolango Regency.

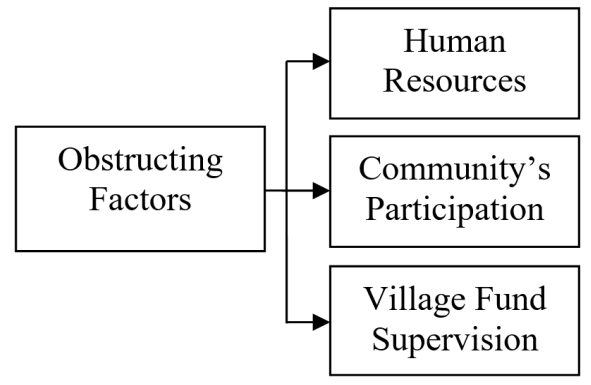

Figure 3. Obstructing Factors of Village Fund

\section{The implementation of Village Fund Policy in Reducing the Poverty Rate in Bone Bolango Regency}

Community empowerment programs are often packaged in an effort to alleviate poverty, even though people who are not in the poverty line also need empowerment (Oleh: 2014). The purpose of the village fund is to develop and empower the community that is distributed from the State Budget. Therefore, development and empowerment are the main priorities. Empirical facts in Bone Bolango Regency reveal that the community's active participation in the village fund program planning has not been optimal. This is evidenced by the discussion of village planning and development that is only formality and still dominated by village officials. This fact is not in compliance with the concept of empowerment as a process to give power to the powerless parties and disempower the dominant parties in order to be equal.

Hence, based on the implementation of village fund policy and the determining factors, an implementation model of the village fund policy that is in line with the area characteristics in Bone Bolango Regency is developed. The development comprises several stages, as follows: 1) Taking the aspiration of the Village Fund Program. This activity is carried out to realize the community's active participation to put on suggestions about important programs and priorities to be accomplished in a year. 2) Village Fund Planning. This stage is performed by taking the community's aspirations and needs through a discussion. In Bone Bolango regency, the discussion is about the village revenue and expenditure budget and village development plans to result in Fund Use Plan (henceforth called as RPD). Village Fund Planning in this area is done through participative planning in the village discussion. 3) Village Fund Budgeting. This process is taken after the discussion results have been approved by all related parties so that the RPD for a year can be arranged. 4) Mechanisms of the Village Fund Disbursement and Distribution. Mechanisms of the village fund disbursement and distribution technically consist of some stages, including completing the required documents and proposing collectively to the sub-district, DPMD, and Regional Financial Management Office. If all documents have been completed, the Regional Financial Management Office will transfer the village fund to each village's bank account. 5) Village Fund Use. The use of village fund is adjusted to the plan that has been arranged with village stakeholders. Village fund is used accountably and refer to the applicable provision. 6) Village Fund Supervision. Supervision is undertaken towards the governance and development so that the implementation does not deviate from the plan and refers to the applicable regulation based on physical implementation or financial management. Village fund is functionally supervised by the authorized supervisors or governmental organizations in Bone Bolango Regency or sub-district level. 7) Village Fund Accountability (Progress Report). Accountability is a consequence over the use of public fund by the village government. Thus, it is essential to compile a progress report administratively regarding the use of the fund. The progress report should refer to the applicable provision for uniformity and 


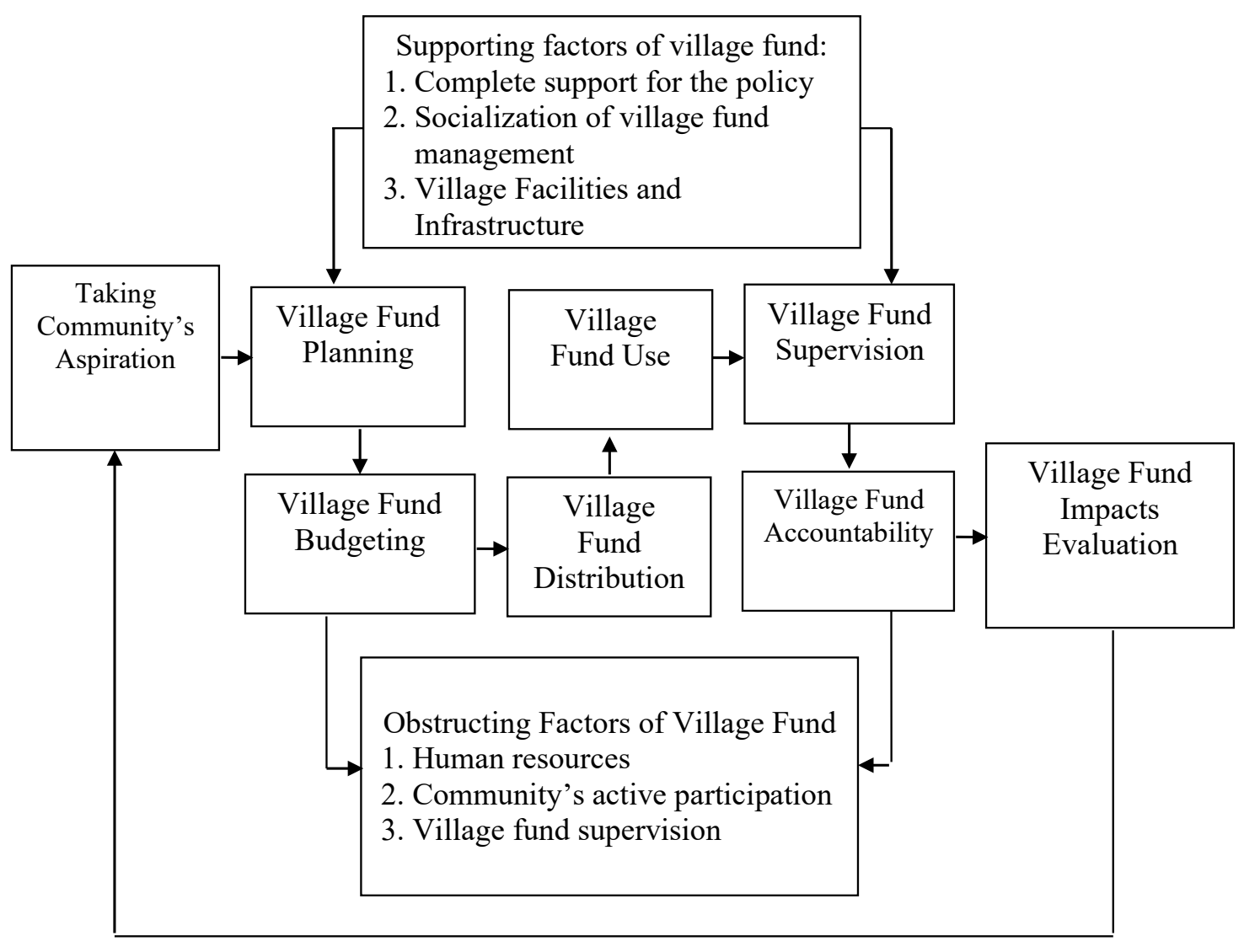

Figure 4. The Development of Implementation Model of the Village Fund Policy in Bone Bolango Regency

legality. 8) Village Fund Impacts Evaluation. This activity is intended to measure the impacts of the success experienced by the community as the targets, particularly in reducing poverty rate in the village.

Figure 4 is the development of implementation model of village fund policy in Bone Bolango Regency.

The development of the implementation model of the village fund policy is vital since it gives an impact on the community's active participation in village development and poverty reduction. Theoretically, Tachjan (2008:18) argues that quality public policy does not only contain ideas or opinions of public administrators but also contain a public opinion as a representation of the public interest.

\section{Conclusions}

The village fund policy over the past four years has not been able to reduce the poverty rate. The implementation of village fund has been yearly conducted through six stages, including planning, distribution, implementation, supervision, accountability, and transparency. Further, the complete support of the policy, socialization of the village fund management participated by the village government, and facilities and infrastructure are the supporting factors of the village fund management. On the other hand, the obstructing factors consist of the availability of human resources as the village fund managers, the community's participation, and the supervision to ensure the effectiveness of village fund implementation.

Development of implementation model of village fund policy is based on various determining factors, such as planning, budgeting, disbursement and distribution mechanisms, usage, supervision, accountability (progress report), and evaluation.

Here are some things needed to enhance the effectiveness of village fund policy to reduce poverty rate: (1) improving the community's active participation in planning, implementing, empowering, supervising, and evaluating the village fund, (2) arranging prioritized and measurable village fund work plans and reaching the poor people's basic needs, (3) preparing human resources as the implementation team of village fund, (4) 
creating innovative and productive programs for poverty reduction, (5) fulfilling the access of public services in the village.

\section{Acknowledgment}

I would like to thank the Government of Bone Bolango Regency, Gorontalo Province.

\section{References}

Abdulsyani. (2007), Sosiologi Skematika, Teori dan Terapan. Jakarta: PT. Bumi Aksara.

Abidin, Muhammad Zainul. (2015). Tinjauan atas Pelaksanaan Keuangan Desa dalam Mendukung Kebijakan Dana Desa. Jurnal Ekonomi \& Kebijakan Publik. Vol. 6 No. 1, hlm 61-76.

Act Number 6 of 2014 on Villages

Act Number 32 of 2004 on Local Government.

Act Number 33 of 2004 on Financial Balance between Central and Local Governments.

Act Number 6 of 2003 on Establisment of Bone Bolango Regency and Pohuwato Regency in Gorontalo Provinsi.

Anderson, James E. (1984). Public PolicyMaking. USA: CBS College Publishing.

Anwar Saiful. (2020). Implementasi Kebijakan Pengelolaan Dana Desa: Zaltman's Metaphor Elicitation Technique, (Studi Empirik di Kabupaten Semarang, Provinsi Jawa Tengah, Indonesia) Jurnal Akuntansi \& Ekonomi FE. UN PGRI Kediri Vol. 5 No 1, Maret ISSN: 2541-0180

Aswar. (2017). Implementasi Kebijakan Pengelolaan Alokasi Dana Desa Di Desa Siboang Kecamatan Sojol Kabupaten Donggala, e Jurnal Katalogis, Volume 5 Nomor 12, Desember hlm 99-107

Badan Pusat Statistik Kabupaten Bone Bolango. (2018). Data tingkat kemiskinan penduduk di Kabupaten Bone Bolango Tahun 2014 s.d 2017.

Chasanah Khuswatun, Rosyadi Slamet, Kurniasih Denok, (2017), Implementasi Kebijakan Dana Desa, IJPA-The Indonesian Journal of Public Administration, Volume 3 | Nomor 2 | Desember, Copyright (c) 2017|IJPA|E-ISSN:2460-0369

Crisbiantoro Jefry, Takwim. (2019). Implementasi Kebijakan Pengelolaan Dana Desa Dalam Meningkatkan Percepatan Pembangunan Di Kabupaten Konawe, Jurnal Akrab Juara Volume 4 Nomor 5 Edisi Desember 2019 (127-141)

Dinas Pemberdayaan masyarakat dan desa Kabupaten Bone Bolango. (2018). Realisasi Penyaluran Dana Desa Tahun
2015 s.d 2018.

Fahri Lutfhi Nur. 2017). Pengaruh Pelaksanaan Kebijakan Dana Desa terhadap Manajemen Keuangan Desa dalam Meningkatkan Efektivitas Program Pembangunan Desa, Jurnal Publik Vol. $11 ;$ No. $01 ; 2017 ; 75-88$

Government Regulation Number 60 of 2014 on Village Fund.

Government Regulation Number 43 of 2014 on Implementation Regulation of Act Number 60 of 2014 on Villages.

Hertati Diana. (2018). Arif Lukman, Implementasi Kebijakan Pengelolaan Dana Desa di Desa Pejambon Kabupaten Bojonegoro Jawa Timur, Journal of Economics, Business, and Government Challenges, JoEBGC Vol. 1, No. 1, pp. 4049, FEB UPNVJT. All right reserved ISSN 1979-7117 e-ISSN 2614-4115

Herlina Ade, Hermana Dody. (2018). Pengaruh Implementasi Kebijakan Alokasi Dana Desa Terhadap Efektivitas Pembangunan Fisik Di Desa Sukatani Kecamatan Cisurupan Kabupaten Garut, Jurnal Pembangunan dan Kebijakan Publik, Fakultas ISIP Universitas Garut, Vol. 09; No. 02

Kamaludin. (2018). Implementasi Kebijakan Alokasi Dana Desa Di Wilayah Desa Maria Kecamatan Wawo Kabupaten Bima, Jurnal Komunikasi dan Kebudayaan Volume 5, Nomor 1, Juni, ISSN: 2443-3519

Lester, James P. And Joseph Stewart. (2000). Public Policy: An Evolutionary Approach. Australia: Wadsworth. Second Edition.

Lawrence Neuman, William. (2000). Social Research Methods. Qualitative and Quantitative Approach, 4th Edition. USA; Allyn \& Bacon.

Miles, Huberman dan Saldana (2014). Qualitative Data analysis, A. Sourcebook of new methods, Veverly Hills, Sage publication.

Makmur. (2011). Efektivitas Kebijakan Pengawasan. Bandung PT. Refika Aditama.

Moenir, A.S (1992). Manajemen Pelayanan Umum di Indonesia. Jakarta : Bumi Aksara

Mulyadi Deddy. (2019). Implementasi Kebijakan Pemberian Bantuan Keuangan Kepada Pemerintah Desa Di Kabupaten Bandung Policy Implementation To Financial Fund Assistance To Village Government In Bandung District, Jurnal Ilmu Administrasi (JIA) Media Pengembangan Ilmu dan Praktek Administrasi, Volume XVI | Nomor 1 | Juni

Mustanir Ahmad. (2016). Implementasi Kebijakan Dana Desa Dan Partisipasi Masyarakat Dalam Pembangunan Di Desa Teteaji Kecamatan Tellu Limpoe 
Kabupaten Sidenreng Rappang, Darmiah, Jurnal Politik Profetik Volume 04, No. 2 Tahun 2016, ISSN: 2337-4756

Oleh Helen Florensi. (2014). Pelaksanaan Kebijakan Alokasi Dana Desa (ADD) dalam Memberdayakan Masyarakat Desa di Desa Cerme, Kecamatan Grogol, Kabupaten Kediri, Jurnal Kebijakan dan Manajemen Publik, Volume 2, Nomor 1, Januari 2014, ISSN 2303 - 341X

Prasetyo, Yudhi \& Gregorius Nasiansenus Masdjojo. (2014). Implementasi Kebijakan Alokasi Dana Desa di 10 Desa Wilayah Kecamatan Rembang Kabupaten Rembang. Jurnal Administrasi Publik. Vol. 1 No. 6, hlm 302.

Pratama Agung, K. Suhendra, Siswoyo Mukarto. (2019). Implementasi Kebijakan Penggunaan Dana Desa Di Kabupaten Indramayu (Studi Kasus Penetapan Prioritas Dana Desa di Kecamatan Sliyeg Kabupaten Indramayu), Redaksi Jurnal Ilmu Administrasi REFORMASI Universitas Swadaya Gunung Jati, | Nomor 1 | Jilid 4 | Agustus

Government Regulation Number 60 of 2014 on Village Fund

Government Regulation Number 43 of 2014 on Implementation Regulation of Act Number 60 of 2014 on Villages

Riadi Slamet, Sawitri Anna, Suasa. (2020). Implementasi Kebijakan Alokasi Dana Desa Di Desa Tolole Kecamatan Ampibabo Kabupaten Parigi Moutong, Jurnal MODERAT, Volume 6, Nomor 3, 2020, ISSN: 2442-3777 (cetak) Website: https://jurnal.unigal.ac.id/index.php/ moderat ISSN: 2622-691X (online)

Ridwan Mohammad, Ibty Idham. (2019). Implementasi Kebijakan Dana Desa Tahun 2016 Di Desa Sukoharjo Ngaglik Sleman Yogyakarta, Jurnal Enersia Publika:
Energi, Sosial dan Administrasi Publik, Vol. 3, No. 2, Des, hal 113-125

Rokhman Wahibur. (2011). Manajemen Sumberdaya Manusia, Nora Media Enterprise, Kudus.

Rozaki Abdur, dkk. (2005). Prakarsa Desentralisasi dan otonomi desa. Yogyakarta. IRE Press.

Slamet, Y. (1994). Pembangunan masyarakat berwawasan partisipasi, Surakarta sebelas maret university press.

Suryono, Agus. (2001). Teori dan Isi Pembangunan. Malang, Universitas Negeri Malang. UM Press.

Sumaryadi, I Nyoman. (2005). Perencanaan Pembangunan Daerah Otonom dan Pemberdayaan Masyarakat. Jakarta. Citra Utama.

Tachjan. (2008). Implementasi Kebijakan Publik/implementation of public polict, Bandung; Publisher AIPI Bandung-Puslit KP2W Lemlit Unpad

Utama Lalu Satria, Effendy Khasan, Ngadisah, Wildan Lalu, 2019, Analisis Implementasi Kebijakan Dana Desa Dalam Meningkatkan Kemandirian Desa Di Kabupaten Lombok Tengah Provinsi NTB, Jurnal Media Bina Ilmiah, Media Bina Ilmiah, ISSN 19783787 (print) | 2615-3505 (online), Vol.14 No.1 Agustus.

Wahyuddin. (2019). Implementasi Kebijakan Alokasi Dana Desa Di Desa Ako Kecamatan Pasangkayu Kabupaten Mamuju Utara, e Jurnal Katalogis, Volume 4 Nomor 5, Mei, hlm 141-149, ISSN: 2302.

Winarni Fransisca dan Yuanjaya Pandhu. (2016). Implementasi Kebijakan Dana Desa Dalam Meningkatan Pembangunan Di Desa Wukirsari, Kabupaten Sleman, NATAPRAJA Jurnal Kajian Ilmu Administrasi Negara, Volume 4 Nomor 1 Tahun 2016 Halaman 49-64. 